\title{
New Fluorenocrownophanes with Naphthalene Fragments: Synthesis, Structure, Properties, and Interaction with Paraquat
}

\author{
A. Yu. Lyapunov, ${ }^{a}$ A. V. Lobach, ${ }^{a}$ I. S. Yakovenko, ${ }^{a}$ E. Yu. Kulygina, ${ }^{a}$ \\ S. V. Shishkina, ${ }^{\text {b,c }}$ R. I. Zubatyuk, ${ }^{b}$ and T. I. Kirichenko ${ }^{\mathrm{a} @}$ \\ ${ }^{a}$ A.V. Bogatsky Physico-Chemical Institute, National Academy of Sciences of Ukraine, 65080 Odessa, Ukraine \\ 'SSI "Institute for Single Crystals”, National Academy of Sciences of Ukraine, 61001 Kharkiv, Ukraine \\ ${ }^{ }$V.N. Karazin Kharkiv National University, 61022 Kharkiv, Ukraine \\ ${ }^{\circledR}$ Corresponding authorE-mail: ti-kirichenko@rambler.ru
}

\begin{abstract}
New crownophanes containing fragments of 1,5-dioxynaphthalene and 2,7-dioxyfluorene or 2,7-dioxyfluorene were synthesized by reduction of the corresponding fluorenonocrownophanes. $H_{2}-\mathrm{Pd} / \mathrm{C}$ or Wolff-Kishner methods were utilized. Molecular structure of bis(fluoreno)crownophane with tetraethyleneglycol linkers was confirmed by singlecrystal X-ray diffraction. The formation of pseudorotaxane-type host-guest complexes of the obtained crownophanes with paraquat dication was detected by FABMS, ${ }^{1} H$ NMR and UV-Vis spectroscopy.
\end{abstract}

Keywords: Fluorenocrownophanes, fluorenonocrownophanes, reduction, paraquat, pseudorotaxanes.

\section{Новые флуоренокраунофаны с фрагментами нафталина: синтез, структура, свойства и взаимодействие с паракватом}

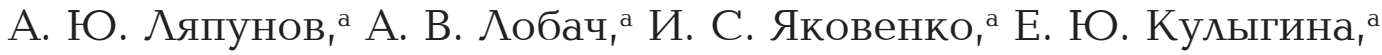 \\ С. В. Шишкина, ${ }^{\text {b, }}$ Р. И. Зубатюк, ${ }^{\text {b T. И. Кириченко }}{ }^{\mathrm{Q}}$ \\ аФизико-химический институт имени А.В. Богатского Наџиональной академии наук Украины, 65080 Одесса, \\ Украина \\ ${ }^{\mathrm{b}}$ НТК “Институт монокристаллов” Национальной академии наук Украины, 61001 Харьков, Украина \\ 'Харьковский национальный университет имени В.Н. Каразина, 61022 Харьков, Украина \\ ${ }^{\circledR}$ E-mail: ti-kirichenko@rambler.ru
}

\begin{abstract}
Восстановлением соответствующих флуоренонокраунофанов в системе $\mathrm{H}_{2}-\mathrm{Pd} / \mathrm{C}$ либо в условиях реакиии Кижнера-Вольфа получены новые флуоренокраунофаны, содержашие два фрагмента 2,7-диоксифлуорена либо фрагменть 2,7-диоксифлуорена и 1,5-диоксинафталина. Строение молекуль бис(флуорено)краунофана с фрагментами тетраэтиленгликоля было подтверждено методом РСА. Методами ББА-масс-спектрометрии, ${ }^{1}$ Н ЯМР и электронной спектроскопии установлено образование псевдоротаксанов при взаимодействии полученных краунофанов с паракват-дикатионом.
\end{abstract}

Ключевые слова: Флуоренокраунофаны, флуоренонокраунофаны, восстановление, паракват, псевдоротаксаны. 


\section{Introduction}

The contemporary chemistry of cyclophanes has shifted its focus from pure synthetic and structural studies to the study of properties which give way to practical applications. In the last decade cyclophanes and crownophanes - their polyether analogs, have been actively employed for the synthesis of supramolecular structures such as pseudorotaxanes, rotaxanes and catenanes. ${ }^{[1-3]}$ The practical goal of these studies was to create novel compounds that are able to form strong complexes with electron-deficient substrates which can then be used to construct supramolecular and sensor systems. ${ }^{[4-7]}$

The fluorene moiety, as well as its derivative fluorenone, has a large $\pi$-electron system and the removal of the carbonyl group results in increased electron density and the uniformity of its distribution. The methylene protons in position 9 can act as a "probe" as they are situated out of the plane of the aromatic rings and should be most sensitive to the spatial environment changes of the molecule, which can be used for study of complexation properties by NMR. Moreover, the fluorene fragment has excellent fluorescent and electrochemical properties and cyclophanes constructed from fluorene play an important role in the creation of organic light emitting diodes (OLED) ${ }^{[8,9]}$ charge transporters, ${ }^{[10,11]}$ transistors, ${ }^{[12]}$ sensors, ${ }^{[13]}$ and two-photon absorption materials. ${ }^{[14]}$ Though a large number of compounds has been described, the search for novel macrocyclic compounds including the fluorene moiety is still actual.

We have earlier described the synthesis of fluorenocrownophanes containing 2,7-dioxyfluorene and hydroquinone or 4,4'-dioxybiphenyl, the qualitative assessment of their paraquat complexes demonstrated the perspectives of further investigation of their complexation properties. ${ }^{[15]}$ In the light of the above, the current research was aimed at describing the influence of the second aromatic ring on the properties of fluorenocrownophanes. To achieve this we have synthesized novel fluorenocrownophanes containing either two fluorene or one fluorene and one naphthalene fragments and performed a qualitative study of the complex formation with model electron-deficient substrate - paraquat-dication in order to evaluate the perspectives of the further studies.

\section{Experimental}

The ${ }^{1} \mathrm{H}$ and ${ }^{13} \mathrm{C}$ NMR spectra were recorded on Varian VXR$300\left({ }^{1} \mathrm{H}\right)$ and Bruker Avance DRX $500\left({ }^{13} \mathrm{C}\right)$ instruments with the operating frequencies of 300 and $125.76 \mathrm{MHz}$ correspondingly, the ${ }^{1} \mathrm{H}$ spectra of the complexes were recorded in a mixture of $\mathrm{CD}_{3} \mathrm{CN}-\mathrm{CDCl}_{3}(4: 3, \mathrm{v} / \mathrm{v})$. The EI mass spectra were obtained on a MX-1321 mass spectrometer (70 eV, direct injection), the FAB mass spectra were obtained on a VG 7070EQ mass spectrometer $(\mathrm{Xe}, 8 \mathrm{kV}$ ) in a matrix of 3-nitrobenzyl alcohol. The UV-Vis spectra were recorded on a Specord M-40 spectrophotometer. The elemental analysis was conducted on a EuroVector CHNS analyzer. The melting points were measured using open capillaries and were not corrected. The purity of all the compounds synthesized were monitored by TLC $\left(\mathrm{Al}_{2} \mathrm{O}_{3} / \mathrm{Al}\right.$ plates by Fluka and $\mathrm{SiO}_{2}$ Sorbfil UV254). Preparative flash chromatography was performed on silica gel 60 ( $<63 \mathrm{mcm}$, Merck KGaA). X-Ray structure study of compound 2c was performed on an «Xcalibur-3» diffractometer $\left(\mathrm{MoK}_{\alpha}\right.$ radiation, CCD-detector, graphite monochromator, $\omega$-scan, $2 \theta_{\max }=$ $60^{\circ}$ ). The structure was solved by direct methods using SHELXTL software. ${ }^{[16]}$ The positions of hydrogen atoms were derived from differential electron density synthesis and refined within riding model with fixed isotropic displacement parameters with $U_{\text {iso }}$ $=1.2 \mathrm{U}_{\mathrm{eq}}$ of a non-hydrogen atom bound to the current hydrogen atom. The structure was refined by full-matrix least squares technique on $\mathrm{F}^{2}$ with anisotropic displacement parameters for nonhydrogen atoms with $\mathrm{wR}_{2}=0.054$ for 10235 reflections $\left(\mathrm{R}_{1}=0.039\right.$ for 5510 reflections with $\mathrm{F}>4 \sigma(\mathrm{F}), \mathrm{S}=0.963)$, CCDC 1410263. 1,5-Dimethoxynaphthalene was purchased from commercial sources. Fluorenonocrownophanes 1a-c,e-g, ${ }^{[17-19]}$ and paraquat bis(hexafluorophosphate) $6 \cdot 2 \mathrm{PF}_{6}{ }^{[20]}$ were obtained by previously described procedures.

\section{Synthesis}

$8,11,14,17,20,23,35,38,41,44,47,50$-Dodecaoxaheptacyclo $\left[49 \cdot 3 \cdot 1 \cdot 1^{3,7} \cdot 1^{24,28} \cdot 1^{30,34} \cdot 0^{4,54} \cdot 0^{27,31}\right]$ octapentaconta-1(55),3(58), 4,6, 24(57),25,27,30(56),31,33,51,53-dodecaen-2,29-dione (1d). To a suspension of $5.52 \mathrm{~g}(0.04 \mathrm{~mol})$ of anhydrous potassium carbonate in $600 \mathrm{~mL}$ of dry DMF was added with stirring a solution of 0.01 mol of 2,7-dihydroxyfluorenone and $0.01 \mathrm{~mol}$ of the corresponding bistosylate ${ }^{[17]}$ in $400 \mathrm{~mL}$ of dry DMF. The addition was performed for $10 \mathrm{~h}$ while the temperature of the reaction mixture was maintained at $80{ }^{\circ} \mathrm{C}$. When the addition was finished the mixture was stirred for extra $40 \mathrm{~h}$ at the same temperature. The cooled reaction mixture was filtered and the solvent evaporated in vacuo. The residue was extracted with two toluene portions of 600 and $400 \mathrm{~mL}$, the solvent was evaporated in vacuo and the residue was subjected to chromatographic purification $\left(\mathrm{SiO}_{2}, \mathrm{CHCl}_{3}-\mathrm{CH}_{3} \mathrm{OH}, 100: 3\right)$ and recrystallization from toluene. Orange powder. Yield: $4.39 \mathrm{~g}$ (53 \%), m.p. $172-173{ }^{\circ} \mathrm{C}$. Found, \%: C 66.87, H 6.40. $\mathrm{C}_{46} \mathrm{H}_{52} \mathrm{O}_{14}$. Calculated, \%: C 66.65, H 6.32. $\mathrm{m} / z$ (EI) $I_{\text {rel }}, \%: 828[\mathrm{M}]^{+}(24)$, 239 (15), 211 (12), 45 (100). UV-Vis $\left(\mathrm{C}_{4} \mathrm{H}_{8} \mathrm{O}_{2}\right) \lambda_{\text {max }}(\lg \varepsilon) \mathrm{nm}: 263$ (5.04), 271 (5.03), 302 (4.09), 314 (4.06), 468 (2.66). ${ }^{1} \mathrm{H}$ NMR $\left(\mathrm{CDCl}_{3}\right) \delta_{\mathrm{H}} \mathrm{ppm}(\mathrm{J}, \mathrm{Hz}): 3.67-3.77\left(\mathrm{~m}, 24 \mathrm{H}, \mathrm{CH}_{2} \mathrm{O}\right), 3.87(\mathrm{t}, 8 \mathrm{H}, J$ $\left.4.5, \mathrm{CH}_{2} \mathrm{O}\right), 4.04\left(\mathrm{t}, 8 \mathrm{H}, J 4.5, \mathrm{CH}_{2} \mathrm{O}\right), 6.77$ (dd, $4 \mathrm{H}, J 8.4, J 2.2, \mathrm{H}_{\mathrm{b}}$ ), $6.91\left(\mathrm{~d}, 4 \mathrm{H}, J 2.2, \mathrm{H}_{\mathrm{a}}\right), 7.00\left(\mathrm{~d}, 4 \mathrm{H}, J 8.4, \mathrm{H}_{\mathrm{c}}\right) .{ }^{13} \mathrm{C} \mathrm{NMR}\left(\mathrm{CDCl}_{3}\right) \delta_{\mathrm{C}}$ ppm: $67.8,69.6,70.7,70.9$ (2C), 109.9, 120.3, 120.5, 135.6, 137.3, $158.9,193.2$.

Typical procedure for the synthesis of fluorene crownophanes $2 a-d$. A stream of hydrogen was passed for $0.5 \mathrm{~h}$ through a $10 \%$ $\mathrm{Pd} / \mathrm{C}$ suspension $(0.1 \mathrm{~g})$ being stirred in a mixture of $\mathrm{CH}_{3} \mathrm{OH}-$ $\mathrm{PhCH}_{3}(3: 1,40 \mathrm{~mL})$ maintained at $55-60{ }^{\circ} \mathrm{C}$, then a solution $(0.5$ $\mathrm{mmol}$ ) of the corresponding fluorenone crownophane 1a-d with the same temperature and in the same solvent mixture $(80 \mathrm{~mL})$ was added. The stirring was continued, while maintaining the stream of hydrogen and the set temperature until full conversion of the starting material was achieved (20-25 h, TLC). The hot reaction mixture was filtered, the precipitate washed with hot toluene $(5 \times 20$ $\mathrm{mL}$ ), the combined filtrates evaporated in vacuo and the residue was recrystallized from ethanol.

$8,11,14,26,29,32$-Hexaoxaheptacyclo[31.3.1.1 $1^{3,7} \cdot 1^{15,19}$. $\left.1^{21,25} \cdot 0^{4,36} \cdot 0^{18,22}\right]$ tetraconta-1(37), 3(40), 4, 6,15(39), 16,18,21(38), 22,24,33,35-dodecaene (2a). Colorless crystals. Yield: $247 \mathrm{mg}$ (92 \%), m.p.: 241-242 ${ }^{\circ} \mathrm{C}$. Found, \%: C 76.29, H 6.11. $\mathrm{C}_{34} \mathrm{H}_{32} \mathrm{O}_{6}$. Calculated, \%: C 76.10, H 6.01. $\mathrm{m} / z$ (EI) $I_{\text {rel }}, \%$ : $536[\mathrm{M}]^{+}(100)$, 268 (18), 197 (15). UV-Vis $\left(\mathrm{C}_{4} \mathrm{H}_{8} \mathrm{O}_{2}\right) \lambda_{\max }(\lg \varepsilon) \mathrm{nm}: 274$ (4.58), 313 (3.93). ' ${ }^{1} \mathrm{H}$ NMR (DMSO- $\left.d_{6}\right) \delta_{\mathrm{H}} \mathrm{ppm}(J, \mathrm{~Hz}): 2.98\left(\mathrm{~s}, 4 \mathrm{H}, \mathrm{H}_{9}\right), 3.75-$ $3.82\left(\mathrm{~m}, 8 \mathrm{H}, \mathrm{CH}_{2} \mathrm{O}\right), 4.06-4.13\left(\mathrm{~m}, 8 \mathrm{H}, \mathrm{CH}_{2} \mathrm{O}\right), 6.64$ (br.s., $\left.4 \mathrm{H}, \mathrm{H}_{\mathrm{a}}\right)$, $6.86\left(\mathrm{dd}, 4 \mathrm{H}, J 8.1,1.6, \mathrm{H}_{\mathrm{b}}\right), 7.54\left(\mathrm{~d}, 4 \mathrm{H}, J 8.4, \mathrm{H}_{\mathrm{c}}\right)$.

$8,11,14,17,29,32,35,38$-Octaoxaheptacyclo[37.3.1.1 $1^{3,7} \cdot 1^{18,22}$. $\left.1^{24,28} \cdot 0^{4,42} \cdot 0^{21,25}\right]$ hexatetraconta-1(43), 3(46), 4, 6, 18(45), 19, 21 , 24(44),25,27,39,41-dodecaene (2b). Colorless crystals (ethanol). Yield: $193 \mathrm{mg}$ (62\%), m.p.: $148{ }^{\circ} \mathrm{C}$. Found, \%: C 73.11, H 6.62. $\mathrm{C}_{38} \mathrm{H}_{40} \mathrm{O}_{8}$. Calculated, \%: C 73.06, H 6.45. $\mathrm{m} / z$ (EI) $I_{\text {rel }}$, \%: 624 
$[\mathrm{M}]^{+}(100), 312(14), 198(16)$. UV-Vis $\left(\mathrm{CH}_{3} \mathrm{CN}\right) \lambda_{\text {max }}(\lg \varepsilon) \mathrm{nm}: 274$ (4.26), 315 (3.58). ${ }^{1} \mathrm{H} \mathrm{NMR}\left(\mathrm{CDCl}_{3}\right) \delta_{\mathrm{H}} \mathrm{ppm}(J, \mathrm{~Hz}): 3.29(\mathrm{~s}, 4 \mathrm{H}$, $\left.\mathrm{H}_{9}\right), 3.78$ (s, 8H, $\left.\mathrm{CH}_{2} \mathrm{O}\right), 3.89$ (t, 8H, J 4.4, $\left.\mathrm{CH}_{2} \mathrm{O}\right), 4.04$ (t, $8 \mathrm{H}, J$ 4.4, $\left.\mathrm{CH}_{2} \mathrm{O}\right), 6.76\left(\mathrm{~s}, 4 \mathrm{H}, \mathrm{H}_{\mathrm{a}}\right), 6.83\left(\mathrm{~d}, 4 \mathrm{H}, J 8.4, \mathrm{H}_{\mathrm{b}}\right), 7.35(\mathrm{~d}, 4 \mathrm{H}, J$ 8.1, $\left.\mathrm{H}_{\mathrm{c}}\right) .{ }^{13} \mathrm{C} \mathrm{NMR}\left(\mathrm{CDCl}_{3}\right) \delta_{\mathrm{C}} \mathrm{ppm}: 36.9,68.1,70.1,71.3,111.4$, $113.8,119.4,134.8,144.4,157.7$.

$8,11,14,17,20,32,35,38,41,44-D e c a o x a h e p t a c y c l o\left[43 \cdot 3 \cdot 1 \cdot 1^{3,7}\right.$. $\left.1^{21,25} \cdot 1^{27,31} \cdot 0^{4,48} \cdot 0^{24,28}\right]$ dopentaconta-1(49),3(52), 4, 6, 21(51), 22,24, 27(50),28,30,45,47-dodecaene (2c). Colorless crystals. Yield: 189 mg (53 \%), m.p.: $138{ }^{\circ} \mathrm{C}$. Found, \%: C 70.53, H 6.69. $\mathrm{C}_{42} \mathrm{H}_{48} \mathrm{O}_{10}$. Calculated, \%: C 70.77, H 6.79. m/z (EI) $I_{\text {rel }}, \%: 712\left[\left[^{4}\right]^{+}(100)\right.$, 355 (8), 198 (16). UV-Vis $\left(\mathrm{CH}_{3} \mathrm{CN}\right) \lambda_{\max }(\lg \varepsilon) \mathrm{nm}: 273$ (4.32), 315 (3.64). ${ }^{1} \mathrm{H}$ NMR $\left(\mathrm{CDCl}_{3}\right) \delta_{\mathrm{H}} \mathrm{ppm}(J, \mathrm{~Hz}): 3.43\left(\mathrm{~s}, 4 \mathrm{H}, \mathrm{H}_{9}\right), 3.72-$ $3.79\left(\mathrm{~m}, 16 \mathrm{H}, \mathrm{CH}_{2} \mathrm{O}\right), 3.90\left(\mathrm{t}, 8 \mathrm{H}, J 4.4, \mathrm{CH}_{2} \mathrm{O}\right), 4.02(\mathrm{t}, 8 \mathrm{H}, J 4.4$, $\left.\mathrm{CH}_{2} \mathrm{O}\right), 6.78-6.83\left(\mathrm{~m}, 8 \mathrm{H}, \mathrm{H}_{\mathrm{a}}, \mathrm{H}_{\mathrm{b}}\right), 7.34(\mathrm{~d}, 4 \mathrm{H}, J 8.1, \mathrm{H}) .{ }^{13} \mathrm{C} \mathrm{NMR}$ $\left(\mathrm{CDCl}_{3}\right) \delta_{\mathrm{C}}$ ppm: $36.8,67.8,69.8,70.7,70.9,111.0,113.5,119.5$, 134.7, 144.4, 157.6.

$8,11,14,17,20,23,35,38,41,44,47,50$-Dodecaoxaheptacyclo $\left[49 \cdot 3 \cdot 1 \cdot 1^{3,7} \cdot 1^{24,28} \cdot 1^{30,34} \cdot 0^{4,54} \cdot 0^{27,31}\right]$ octapentaconta-1(55),3(58), 4, 6, 24(57),25,27,30(56),31,33,51,53-dodecaene (2d). Colorless crystals. Yield: $128 \mathrm{mg}(32 \%)$, m.p.: $152{ }^{\circ} \mathrm{C}$. Found, \%: C 69.07, H 7.09. $\mathrm{C}_{46} \mathrm{H}_{56} \mathrm{O}_{12}$. Calculated, \%: C 68.98, H 7.05. $\mathrm{m} / z$ (EI) $I_{\text {rel }}$., \%: $800\left[\mathrm{M}^{+}(92), 399(5), 198(100)\right.$. UV-Vis $\left(\mathrm{CH}_{3} \mathrm{CN}\right) \lambda_{\max }(\lg \varepsilon) \mathrm{nm}:$ 275 (4.55), 316 (3.89). ${ }^{1} \mathrm{H}$ NMR $\left(\mathrm{CDCl}_{3}\right) \delta_{\mathrm{H}} \mathrm{ppm}(J, \mathrm{~Hz}): 3.56(\mathrm{~s}$, $\left.4 \mathrm{H}, \mathrm{H}_{9}\right), 3.68-3.75\left(\mathrm{~m}, 24 \mathrm{H}, \mathrm{CH}_{2} \mathrm{O}\right), 3.85\left(\mathrm{t}, 8 \mathrm{H}, J 4.9, \mathrm{CH}_{2} \mathrm{O}\right), 4.05$ $\left(\mathrm{t}, 8 \mathrm{H}, J 4.8, \mathrm{CH}_{2} \mathrm{O}\right), 6.80\left(\mathrm{dd}, 4 \mathrm{H}, J 8.4,1.6, \mathrm{H}_{\mathrm{b}}\right), 6.89\left(\mathrm{~s}, 4 \mathrm{H}, \mathrm{H}_{\mathrm{a}}\right)$, $7.38\left(\mathrm{~d}, 4 \mathrm{H}, J 8.3, \mathrm{H}_{\mathrm{c}}\right) \cdot{ }^{13} \mathrm{C} \mathrm{NMR}\left(\mathrm{CDCl}_{3}\right) \delta_{\mathrm{C}} \mathrm{ppm}: 36.9,67.7,69.8$, 70.7, 70.8, 70.9, 111.2, 113.4, 119.5, 134.7, 144.4, 157.6 .

Typical procedure for the synthesis of fluorene crownophanes $2 \boldsymbol{e}$-g. Hydrazine hydrate $(0.8 \mathrm{~mL}, 16.4 \mathrm{mmol})$ was added to a suspension of $0.4 \mathrm{mmol}$ of the corresponding crownophane 1e-g in $8 \mathrm{~mL}$ of diethylene glycol under an inert atmosphere and the mixture was stirred at $130{ }^{\circ} \mathrm{C}$ until a homogenous bright yellow solution was formed. The mixture was cooled to $100{ }^{\circ} \mathrm{C}$ and $0.2 \mathrm{~mL}$ of $\mathrm{KOH}$ solution was added ( $1 \mathrm{~g} \mathrm{KOH}$ in $5.6 \mathrm{~mL}$ of diethylene glycol) and the temperature was raised up to $200{ }^{\circ} \mathrm{C}$. This temperature was maintained for $5 \mathrm{~min}$, then cooled to $100{ }^{\circ} \mathrm{C}$ and $12 \mathrm{~mL}$ of acidified water were added. The cooled mixture was filtered, the residue was washed several times with water and dried. Column chromatography on $\mathrm{SiO}_{2}$ was then performed using $\mathrm{CH}_{2} \mathrm{Cl}_{2}-2$ propanol 100:1 as the eluent, followed by recrystallization from a suitable solvent.

$8,11,14,17,28,31,34,37$-Octaoxahexacyclo[36.3.1.1 $1^{3,7} \cdot 0^{4,41}$. $\left.0^{18,23} \cdot 0^{22,27}\right]$ tritetraconta-1 (42), 3(43), 4, 6, 18, 20,22, 24, 26, 38, 40undecaene (2e). Recrystallized from 1-butanol. Colorless crystals. Yield: $202 \mathrm{mg}(86 \%)$, m.p.: $138-138.5^{\circ} \mathrm{C}$. Found, \%: C 71.42, $\mathrm{H}$ 6.70. $\mathrm{C}_{35} \mathrm{H}_{38} \mathrm{O}_{8}$. Calculated \%: C 71.65, H 6.53. $\mathrm{m} / \mathrm{z}$ (EI) $I_{\text {rel }}$, \%: $586[\mathrm{M}]^{+}(100), 293$ (32), 198 (14), 45 (21). UV-Vis $\left(\mathrm{CH}_{3} \mathrm{CN}\right)$ $\lambda_{\text {max }}$ (lge) nm: 226 (4.72), 281 (4.39), 313 (3.98), $326(3.93) .{ }^{1} \mathrm{H}$ NMR $\left(\mathrm{CDCl}_{3}\right) \delta_{\mathrm{H}} \mathrm{ppm}(\mathrm{J}, \mathrm{Hz}): 3.07\left(\mathrm{~s}, 2 \mathrm{H}, \mathrm{H}_{9}\right), 3.69-4.00(\mathrm{~m}, 16 \mathrm{H}$, $\left.\mathrm{CH}_{2} \mathrm{O}\right), 4.04-4.22\left(\mathrm{~m}, 8 \mathrm{H}, \mathrm{CH}_{2} \mathrm{O}\right), 6.56\left(\mathrm{~d}, 2 \mathrm{H}, J 7.5, \mathrm{H}_{2,6}\right), 6.77(\mathrm{~s}$, $\left.2 \mathrm{H}, \mathrm{H}_{\mathrm{a}}\right), 6.84\left(\mathrm{~d}, J 8.1,2 \mathrm{H}, \mathrm{H}_{\mathrm{b}}\right), 7.04\left(\mathrm{t}, 2 \mathrm{H}, J 7.9, \mathrm{H}_{3,7}\right), 7.35(\mathrm{~d}, 2 \mathrm{H}$, $\left.J 8.4, \mathrm{H}_{\mathrm{c}}\right), 7.74\left(\mathrm{~d}, 2 \mathrm{H}, J 8.4, \mathrm{H}_{4,8}\right) \cdot{ }^{13} \mathrm{C} \mathrm{NMR}\left(\mathrm{CDCl}_{3}\right) \delta_{\mathrm{C}} \mathrm{ppm:} \mathrm{36.6,}$
$67.568 .4,69.8,70.0,71.0,71.1,77.0,105.2,111.9,114.0,114.2$ 119.1, 124.8, 126.4, 134.7, 144.4, 153.9, 157.3.

$8,11,14,17,20,31,34,37,40,43$-Decaoxahexacyclo $\left[42.3 \cdot 1 \cdot 1^{3,7}\right.$ $\left..0^{4,47} \cdot 0^{21,26} \cdot 0^{25,30}\right]$ nonatetraconta-1(48),3(49), 4,6,21,23,25,27,29,46decaene (2f). Recrystallized from 2-propanol. Colorless crystals. Yield: $182 \mathrm{mg}(66 \%)$, m.p.: $137.5-138{ }^{\circ} \mathrm{C}$. Found, \%: C 69.70, $\mathrm{H}$ 7.03. $\mathrm{C}_{39} \mathrm{H}_{46} \mathrm{O}_{10}$. Calculated \%: C 69.42, H 6.87. $\mathrm{m} / \mathrm{z}$ (EI) $I_{\text {rel }}$, \%: $674[\mathrm{M}]^{+}(100), 337$ (5), 198 (7), 45 (18). UV-Vis $\left(\mathrm{CH}_{3} \mathrm{CN}\right)$ $\lambda_{\max }$ (lge) nm: 226 (4.72), 280 (4.53), 313 (4.12), 327 (4.06). ${ }^{1} \mathrm{H}$ NMR $\left(\mathrm{CDCl}_{3}\right) \delta_{\mathrm{H}} \mathrm{ppm}(\mathrm{J}, \mathrm{Hz}): 3.45\left(\mathrm{~s}, 2 \mathrm{H}, \mathrm{H}_{9}\right), 3.63-3.82(\mathrm{~m}, 16 \mathrm{H}$, $\mathrm{CH}_{2} \mathrm{O}$ ), 3.83-3.97 (m, 8H, $\left.\mathrm{CH}_{2} \mathrm{O}\right), 3.98-4.17\left(\mathrm{~m}, 8 \mathrm{H}, \mathrm{CH}_{2} \mathrm{O}\right), 6.53$ $\left(\mathrm{d}, 2 \mathrm{H}, J 7.8, \mathrm{H}_{2.6}\right), 6.81-6.93\left(\mathrm{~m}, 4 \mathrm{H}, \mathrm{H}_{\mathrm{a}}, \mathrm{H}_{\mathrm{b}}\right), 7.09(\mathrm{t}, 2 \mathrm{H}, J$ 7.9, $\left.\mathrm{H}_{3,7}\right), 7.43\left(\mathrm{~d}, 2 \mathrm{H}, J 8.1, \mathrm{H}_{\mathrm{c}}\right), 7.77\left(\mathrm{~d}, 2 \mathrm{H}, J 8.4, \mathrm{H}_{4,8}\right) .{ }^{13} \mathrm{C} \mathrm{NMR}$ $\left(\mathrm{CDCl}_{3}\right) \delta_{\mathrm{C}}$ ppm: $36.8,67.7,67.9,69.7,69.8,70.7,70.8,70.9(2 \mathrm{C})$, 77.0, 105.3 111.5, 113.4, 114.3, 119.4, 124.9, 126.5, 134.7, 144.3, $154.0,157.4$.

$8,11,14,17,20,23,34,37,40,43,46,49$-Dodecaoxahexacyclo $\left[48 \cdot 3 \cdot 1 \cdot 1^{3,7} \cdot 0^{4,53} \cdot 0^{24,29} \cdot 0^{28,33}\right]$ pentapentaconta-1(54),3(55), 4, 6, 24, 26, 28,30,32,50,52-undecaene (2g). Recrystallized from methanol. Colorless crystals. Yield: $268 \mathrm{mg}(88 \%)$, m.p.: $102-102.5^{\circ} \mathrm{C}$. Found, \%: C 67.82, H 7.10. $\mathrm{C}_{43} \mathrm{H}_{54} \mathrm{O}_{12}$. Calculated \%: C 67.70, H 7.13. $\mathrm{m} / \mathrm{z}$ (EI) $I_{\text {rel }}, \%: 762[\mathrm{M}]^{+}(100), 307$ (29), 198 (23). UV-Vis $\left(\mathrm{CH}_{3} \mathrm{CN}\right)$ $\lambda_{\max }$ (lge) nm: 226 (4.85), 280 (4.53), 313 (4.11), $326(4.06) .{ }^{1} \mathrm{H}$ $\operatorname{NMR}\left(\mathrm{CDCl}_{3}\right) \delta_{\mathrm{H}} \operatorname{ppm}(J, \mathrm{~Hz}): 3.61\left(\mathrm{~s}, 2 \mathrm{H}, \mathrm{H}_{\mathrm{q}}\right), 3.63-3.77(\mathrm{~m}, 24 \mathrm{H}$, $\left.\mathrm{CH}_{2} \mathrm{O}\right), 3.80-3.93\left(\mathrm{~m}, 8 \mathrm{H}, \mathrm{CH}_{2} \mathrm{O}\right), 4.05-4.16\left(\mathrm{~m}, 8 \mathrm{H}, \mathrm{CH}_{2} \mathrm{O}\right), 6.64$ $\left(\mathrm{d}, 2 \mathrm{H}, J 7.5, \mathrm{H}_{2,6}\right), 6.85$ (dd, $\left.2 \mathrm{H}, J 8.4,1.9, \mathrm{H}_{\mathrm{b}}\right), 6.94$ (br.s., $2 \mathrm{H}, \mathrm{H}_{\mathrm{a}}$ ), 7.23 (т, $\left.2 \mathrm{H}, J 8.1, \mathrm{H}_{3,7}\right), 7.45$ (d, 2H, $\left.J 8.1, \mathrm{H}_{\mathrm{c}}\right), 7.78$ (d, 2H, $J$ 8.4, $\left.\mathrm{H}_{4,8}\right) .{ }^{13} \mathrm{C} \mathrm{NMR}\left(\mathrm{CDCl}_{3}\right) \delta_{\mathrm{C}}$ ppm: $36.9,67.7,67.8,69.7,69.8,70.7$ (2C), 70.8 (2C), 70.9, 71.0, 77.0, 105.4, 111.4, 113.5, 114.4, 119.5, 125.0, 134.7, 144.3, 154.1, 157.5.

2,7-Dimethoxy-9H-fluorene (4). A mixture of $2.4 \mathrm{~g}(0.01 \mathrm{~mol})$ of 2,7-dimethoxyfluorenone $(3)^{[15]}$ and $7.3 \mathrm{~mL}(0.15 \mathrm{~mol})$ of hydrazine hydrate in $40 \mathrm{~mL}$ of ethylene glycol was heated in an inert atmosphere at $130-140{ }^{\circ} \mathrm{C}$ until a homogenous solution was formed. The mixture was cooled to $100{ }^{\circ} \mathrm{C}$ and $1.7 \mathrm{~g}(0.03 \mathrm{~mol})$ of $\mathrm{KOH}$ was added, followed by heating to $190{ }^{\circ} \mathrm{C}$ and maintaining the temperature for $5 \mathrm{~min}$. Then an equal volume of water was added to a cooled to $95{ }^{\circ} \mathrm{C}$ mixture and the formed precipitate was filtered, washed with water, dried and recrystallized from toluene with the addition of some $\mathrm{Al}_{2} \mathrm{O}_{3}$. Colorless crystals. Yield: $1.9 \mathrm{~g}$ (86 \%), m.p. $173{ }^{\circ} \mathrm{C}$. Found, \%: C 79.60, H 6.41. $\mathrm{C}_{15} \mathrm{H}_{14} \mathrm{O}_{2}$. Calculated, \%: C 79.62, H 6.24. $\mathrm{m} / z$ (EI) $I_{\text {rel }}, \%: 226[\mathrm{M}]^{+}(100), 211(89) .{ }^{1} \mathrm{H}$ NMR $\left(\mathrm{CDCl}_{3}\right) \delta_{\mathrm{H}} \operatorname{ppm}(J, \mathrm{~Hz}): 3.81\left(\mathrm{~s}, 2 \mathrm{H}, \mathrm{H}_{9}\right), 3.84\left(\mathrm{~s}, 6 \mathrm{H}, \mathrm{CH}_{3}\right), 6.89$ $\left(\mathrm{dd}, 2 \mathrm{H}, J 8.4,2.2, \mathrm{H}_{\mathrm{b}}\right), 7.06\left(\mathrm{~d}, 2 \mathrm{H}, J 2.2, \mathrm{H}_{\mathrm{a}}\right), 7.56\left(\mathrm{~d}, 2 \mathrm{H}, J 8.4, \mathrm{H}_{\mathrm{c}}\right)$.

\section{Results and Discussion}

Bis(fluoreno)crownophanes 2a-d were synthesized in a manner analogous to described in our previous paper ${ }^{[15]}$ by reduction of the corresponding fluorenone crownophanes 1a-d with hydrogen in the presence of $10 \% \mathrm{Pd} / \mathrm{C}$ in a $3: 1$ mixture of methanol and toluene (Scheme 1). The reaction

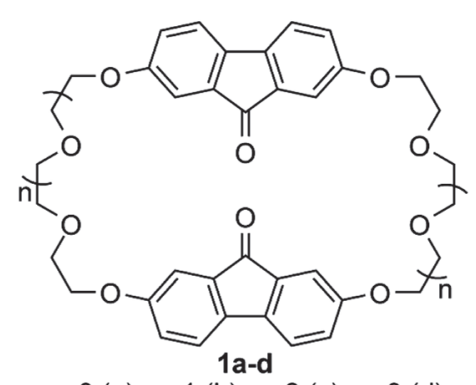

$n=0$ (a), n=1 (b), n=2 (c), n=3 (d)

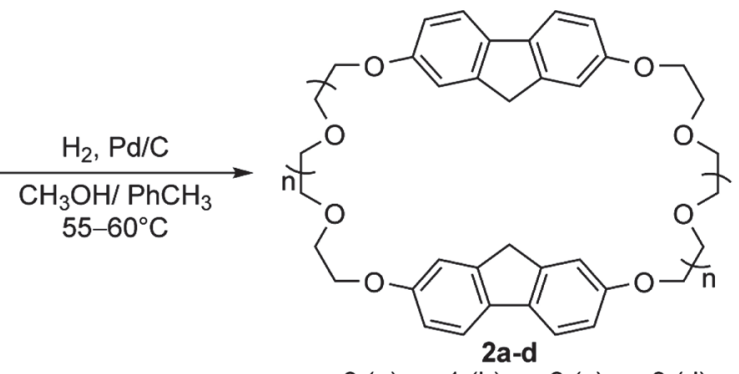

$n=0(a), n=1(b), n=2(c), n=3(d)$

Scheme 1. 
progress was monitored by TLC. After the proper treatment of the reaction mixture and recrystallization of the target compounds from ethanol they were isolated as colorless crystals with $52-92 \%$ yields.

However the attempt to reduce crownophanes 1e-g with a naphthalene fragment under the same conditions did not give satisfactory results. At first, the 9-hydroxy derivative (identified by mass spectrometry) was rapidly accumulated in the reaction mixture. Its further reduction, though, proceeded very slowly compared to the first reaction step, which resulted in the formation of a complex mixture of highly polar compounds instead of the target compound (according to TLC). Changing various reaction parameters, such as increasing the temperature to $60{ }^{\circ} \mathrm{C}$, addition of toluene in order to increase the solubility of the starting crownophane or addition of acetic acid as a catalyst, did not lead to satisfactory results.

Two other general methods for the reduction of a ketone group to a methylene one are the Clemmensen and WolffKishner reactions. The first method could not be utilized due to the low solubility of the starting compounds in water, whilst the reduction of the model 2,7-dimethoxyfluorenone 3 with hydrazine hydrate in ethylene glycol in the presence of $\mathrm{KOH}$ afforded $86 \%$ of 2,7-dimethoxyfluorene 4.

Reduction of 1e-g under the above conditions was found possible only for the crownophane 1g, which has the highest solubility. However, when diethylene glycol was used as the solvent and a large excess (40 eq) of hydrazine hydrate was added, all crownophanes 1e-g were successfully reduced. The excess of hydrazine hydrate and the absence of acidic catalysts prevent the formation of azine side products. After the treatment of the reaction mixture, chromatographic separation and recrystallization the target crownophanes 2e-g were isolated with 66-88 \% yields (Scheme 2 ).

The structure of the synthesized crownophanes $\mathbf{2 a - g}$ was confirmed by NMR spectroscopy, mass spectrometry, elemental analysis, and by X-ray diffraction data for compound 2c.

A typical feature of mass spectra (electron impact) of all the synthesized fluorenocrownophanes $\mathbf{2 a - g}$ is the presence of doubly charged molecular ions $\mathrm{M}^{2+}$, which correspond to half the molecular weight mass, as well as fragmentary ions with the $m / z$ ratios equal to 198 (fluorene residue) and 45 (side chain fragments).

A signal set typical for ethylene glycol oligomers is observed in the ${ }^{1} \mathrm{H}$ NMR spectra of fluorenocrownophanes 2a-g in the $\delta 4.29-3.55 \mathrm{ppm}$ region. The protons of the fluorene fragment are presented as a typical set of signals: a broadened singlet $\left(\mathrm{H}_{\mathrm{a}}\right)$, two doublets $\left(\mathrm{H}_{\mathrm{b}}, \mathrm{H}_{\mathrm{c}}\right)$, and a singlet of $\mathrm{H}_{9}$ methylene group. The protons of 1,5-dioxynaphthalene are represented by two doublets $\left(\mathrm{H}_{2,6}\right.$ and $\left.\mathrm{H}_{4,8}\right)$ and a triplet $\left(\mathrm{H}_{3,7}\right)$. For bis(fluoreno)crownophanes $\mathbf{2 a - d}$ the signals of the aromatic protons undergo an upfield shift compared to their position in the spectrum of 2,7-dimethoxyfluorene 4 . The values of the upfield shift are the greatest for $\mathrm{H}_{\mathrm{a}}$-protons and diminishing simultaneously with increase of the ring size (Table 1).<smiles>COc1ccc2c(c1)C(C)(C)c1c-2cc(C)c(OC)c1C</smiles><smiles>COc1c(C)c(C)c(C)c2c(OC)cccc12</smiles>

Similarly, the signals of all aromatic protons with the exception of $\mathrm{H}_{\mathrm{c}}$ protons in $\mathbf{2} \mathbf{e}-\mathrm{g}$ undergo upfield shifts relative to the position of these signals in the spectra of model compounds $\mathbf{4}$ and $\mathbf{5}$. Such a spectral pattern is a result of mutual shielding of the opposite aromatic fragments of the crownophanes (Table 1). The magnitude of these shifts is decreased with the increase of the ring size. Signals of $\mathrm{H}_{9}$ protons for the above reasons exhibit the greatest upfield shifts, particularly noticeable for bis(fluoreno)crownophanes 2a-d. The singlet form of these protons signal is, obviously, caused by the rapid rotation of the aromatic fragments of fluorenocrownophanes $\mathbf{2 a - g}$ on the NMR time scale. The observed spectral pattern indicates that the aromatic fragments of the crownophanes are spatially close in solutions even in the cases of $\mathbf{2} \mathbf{d}$ and $\mathbf{2} \mathbf{g}$ (according to ${ }^{1} \mathrm{H}$ NMR), where they are linked by pentaethylene glycol residues. Obviously, in solutions the stacking interactions take place with their intensity lowered with the increase of the ring size.

Structure the bis(fluoreno)crownophane $\mathbf{2 c}$ in which the fluorene fragments are linked with tetraethylene glycol residues was confirmed by X-ray structure study. The suitable crystals were obtained by crystallization from acetonitrile. Two molecules (A and B) that have differences in some geometric parameters are identified in the independent part of a unit cell. Each molecule is in a particular position relative to the inversion center; as a result half of the molecule is symmetrically independent.

In both molecules the $\pi$-systems of the fluorene fragments are almost not overlapped. The conformational flex-
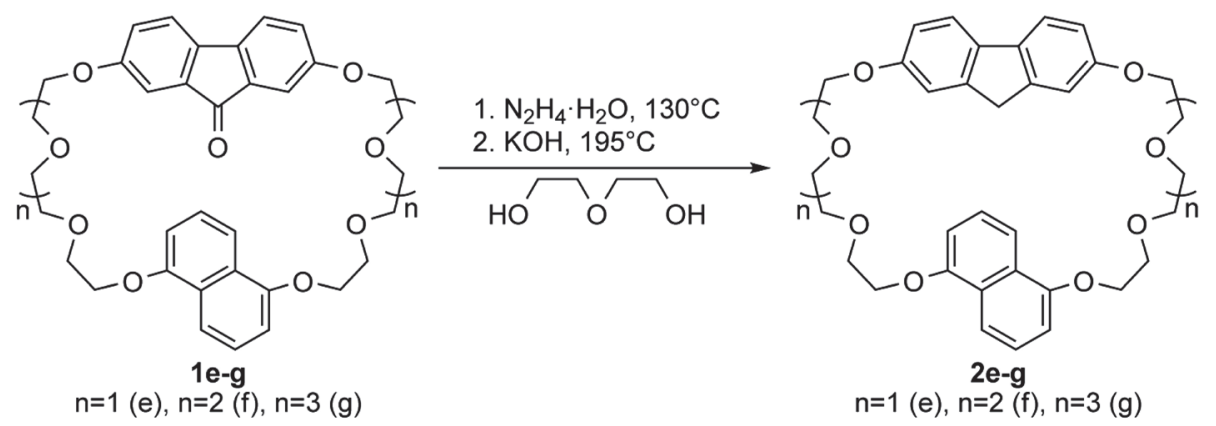

Scheme 2. 
Table 1. Absolute $(\delta, \mathrm{ppm})$ and relative $\left(\Delta \delta^{1}, \mathrm{ppm}\right)$ chemical shifts of the aromatic protons ${ }^{2}$ of crownophanes $\mathbf{2 a - g}$ and model compounds 4 and $\mathbf{5}$ in $\mathrm{CDCl}_{3}$ at $298 \mathrm{~K}$.

\begin{tabular}{|c|c|c|c|c|c|c|c|c|c|c|c|c|c|c|}
\hline \multirow{2}{*}{ Compound } & \multicolumn{2}{|c|}{$\mathrm{H}_{9}$} & \multicolumn{2}{|c|}{$\mathrm{H}_{\mathrm{a}}$} & \multicolumn{2}{|c|}{$\mathrm{H}_{\mathrm{b}}$} & \multicolumn{2}{|c|}{$\mathrm{H}_{\mathrm{c}}$} & \multicolumn{2}{|c|}{$\mathrm{H}_{2,6}$} & \multicolumn{2}{|c|}{$\mathrm{H}_{3,7}$} & \multicolumn{2}{|c|}{$\mathrm{H}_{4,8}$} \\
\hline & $\delta$ & $-\Delta \delta$ & $\delta$ & $-\Delta \delta$ & $\delta$ & $-\Delta \delta$ & $\delta$ & $-\Delta \delta$ & $\delta$ & $-\Delta \delta$ & $\delta$ & $-\Delta \delta$ & $\delta$ & $-\Delta \delta$ \\
\hline $2 a^{3}$ & 2.98 & 0.83 & 6.64 & 0.42 & 6.86 & 0.03 & 7.54 & 0.02 & - & - & - & - & - & - \\
\hline $2 b$ & 3.29 & 0.52 & 6.76 & 0.30 & 6.83 & 0.06 & 7.35 & 0.21 & - & - & - & - & - & - \\
\hline $2 c$ & 3.43 & 0.38 & $6.81^{4}$ & 0.25 & $6.81^{4}$ & 0.08 & 7.34 & 0.22 & - & - & - & - & - & - \\
\hline 2d & 3.56 & 0.25 & 6.89 & 0.17 & 6.80 & 0.09 & 7.38 & 0.18 & - & - & - & - & - & - \\
\hline $2 e$ & 3.07 & 0.74 & 6.77 & 0.29 & 6.84 & 0.05 & 7.35 & 0.21 & 6.56 & 0.27 & 7.04 & 0.32 & 7.74 & 0.09 \\
\hline $2 f$ & 3.45 & 0.36 & $6.88^{4}$ & 0.18 & $6.85^{4}$ & 0.04 & 7.43 & 0.13 & 6.54 & 0.29 & 7.09 & 0.27 & 7.76 & 0.07 \\
\hline $2 \mathrm{~g}$ & 3.61 & 0.20 & 6.94 & 0.12 & 6.85 & 0.04 & 7.44 & 0.12 & 6.64 & 0.19 & 7.23 & 0.13 & 7.78 & 0.05 \\
\hline 4 & 3.81 & - & 7.06 & - & 6.89 & - & 7.56 & - & - & - & - & - & - & - \\
\hline 5 & - & - & - & - & - & - & - & - & 6.83 & - & 7.36 & - & 7.83 & - \\
\hline
\end{tabular}

${ }^{1} \Delta \delta$ is equal to the difference of chemical shifts of the corresponding protons in compounds $\mathbf{2 a - d}$ and $\mathbf{4}$, and compounds $\mathbf{2 e - f}$ and $\mathbf{4}, \mathbf{5}$, correspondingly.

${ }^{2}$ The proton enumeration was given above.

${ }^{3}$ In DMSO- $d$.

${ }^{4}$ The signals of $\mathrm{H}_{\mathrm{a}}$ and $\mathrm{H}_{\mathrm{b}}$ overlap, which hinders the determination of the exact signal positions.

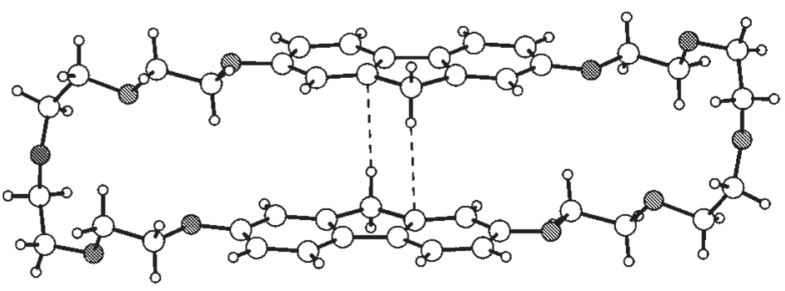

A

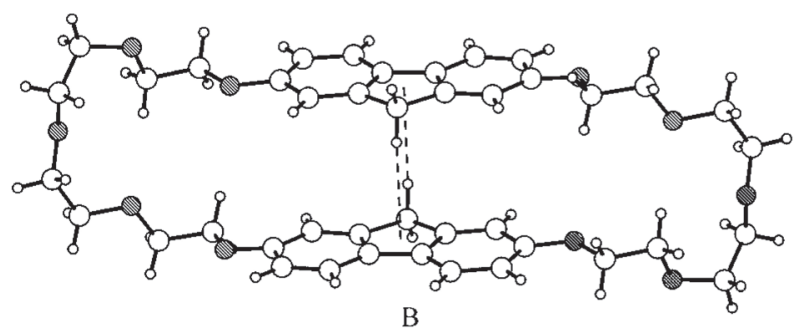

$\mathrm{B}$

Figure 1. Molecules A and B of compound 2c, identified in the independent part of the unit cell.

ibility of tetraethylene glycol residues provide a shift of fluorene fragments respectively each other in the direction perpendicular to the most elongated dimension of the triple ring. The main difference between $\mathrm{A}$ and $\mathrm{B}$ molecules is the position of the fluorene fragments with respect to each other along the linker chain (Figure 1): in A the fluorene fragments are slightly shifted compared to B. The mutual disposition of the fluorene fragments is stabilized by two symmetric intramolecular $\mathrm{C}-\mathrm{H} \cdots \pi$ hydrogen bonds $\mathrm{C}_{7}-\mathrm{H}_{7 \mathrm{ab}} \cdots \mathrm{C}_{8},(\mathrm{H} \cdots \mathrm{C}$ $2.76 \AA, \mathrm{C}-\mathrm{H} \cdots \mathrm{C} 145^{\circ}$ ) for molecule $\mathrm{A}$, and $\mathrm{B} \mathrm{C}_{7}-\mathrm{H}_{7 \mathrm{ba}} \cdots \mathrm{X}$ (where $\mathrm{X}$ is the geometric center of the $\mathrm{C}_{1}-\mathrm{C}_{6}-\mathrm{C}_{7}-\mathrm{C}_{8}-\mathrm{C}_{13}$ ring) $\left(\mathrm{H} \cdots \mathrm{X} 2.72 \AA, \mathrm{C}-\mathrm{H} \cdots \mathrm{X} 153^{\circ}\right)$ for molecule $\mathrm{B}$.

In crystals, molecules $\mathrm{A}$ and $\mathrm{B}$ interleave forming stacks (Figure 2) lying in the crystallographic plane (1 $0-1)$. Inside the stacks the molecules are linked with $\mathrm{C}-\mathrm{H} \cdots \pi$ intermolecular hydrogen bonds $\mathrm{C}_{12}-\mathrm{H}_{12 \mathrm{a}} \cdots \mathrm{C}_{10 \mathrm{~b}},(\pi)(-\mathrm{x}, 2-\mathrm{y}$, $-\mathrm{z}) \mathrm{H} \cdots \mathrm{C} 2.86 \AA \mathrm{C}-\mathrm{H} \cdots \mathrm{C} 138^{\circ} ; \mathrm{C}_{2}-\mathrm{H}_{2 \mathrm{aa}} \cdots \mathrm{C}_{1 \mathrm{~b}^{\prime}}(\pi)(-\mathrm{x}, 2-\mathrm{y}$, $-\mathrm{z}) \mathrm{H} \cdots \mathrm{C} 2.69 \AA \mathrm{C}-\mathrm{H} \cdots \mathrm{C} 152^{\circ} ; \mathrm{C}_{2}-\mathrm{H}_{2 \mathrm{a}} \cdots \mathrm{C}_{6 \mathrm{~b}},(\pi)(-\mathrm{x}, 2-\mathrm{y}$, $-\mathrm{z}) \mathrm{H} \cdots \mathrm{C} 2.85 \AA \mathrm{C}-\mathrm{H} \cdots \mathrm{C} 141^{\circ}$.

The neighboring stacks (Figure 3 ) are linked with intermolecular hydrogen bonds of $\mathrm{C}_{15 \mathrm{a}}-\mathrm{H}_{15} \cdots \mathrm{C}_{12 \mathrm{~b}},(\pi)(-\mathrm{x}$, $-0.5+\mathrm{y}, 0.5-\mathrm{z}) \mathrm{H} \cdots \mathrm{C} 2.76 \AA \mathrm{C}-\mathrm{H} \cdots \mathrm{C} 141^{\circ}$ and $\mathrm{C}_{16 \mathrm{~b}}-\mathrm{H} \cdots \mathrm{C}_{2 \mathrm{~b}}$, $(\pi)(\mathrm{x}, 2.5-\mathrm{y},-0.5+\mathrm{z}) \mathrm{H} \cdots \mathrm{C} 2.82 \AA \mathrm{C}-\mathrm{H} \cdots \mathrm{C} 116^{\circ}$.

Complex of spectral methods was used to demonstrate that all previously synthesized fluorene- and fluorenonocrownophanes form host-guest complexes with paraquat

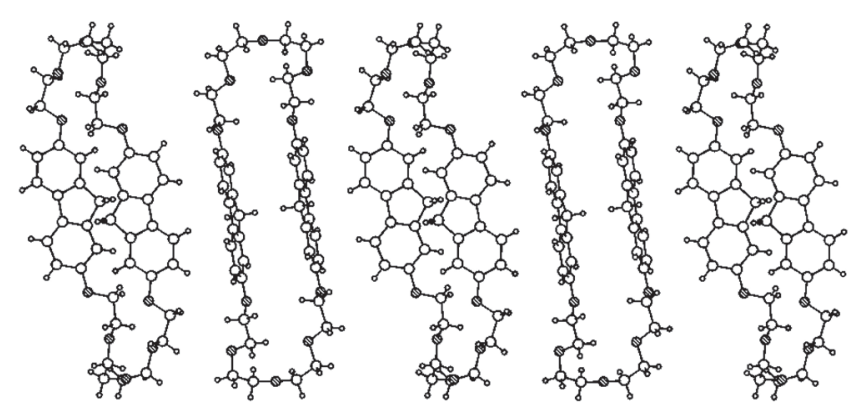

Figure 2. Interleaved molecules A and B in a crystal.

bis(hexafluorophosphate) $6 \cdot 2 \mathrm{PF}_{6}$, which is one of the most studied electron-deficient guests in macrocyclic chemistry. [17-19,21-24] This methodology was used for the studies of the crownophanes $\mathbf{2 a - g}$ as well.<smiles>C[n+]1ccc(-c2cc[n+](C)c(P)c2P)cc1</smiles> 


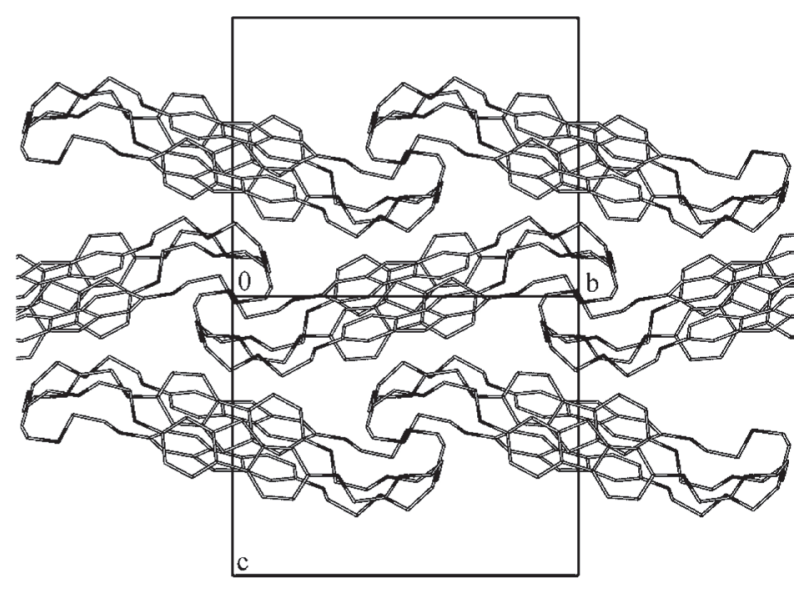

Figure 3. The packing of the stacks in a crystal.

For the qualitative assessment of the possibility of inclusion complexes formation and their relative stability the competitive complex formation method was employed under the FAB mass spectrometry conditions. ${ }^{[25-27]}$ Two solutions containing equimolar amounts of crownophanes 2b-d or 2e-g and 3 equivalents of $\mathbf{6} \cdot 2 \mathrm{PF}_{6}$ in 3-nitrobenzyl alcohol were subjected to mass spectral analysis. In the mass spectra, besides the initial crownophanes peaks, the peaks of ions corresponding to the formation of a crownophaneparaquat 1:1 complex with the loss of a hexafluorophosphate anion were observed (Table 2).

Table 2. Normalized peak intensities of the complex ions of crownophanes $\mathbf{2 b}-\mathbf{g}$ and paraquat $\mathbf{6} \cdot 2 \mathrm{PF}_{6}$.

\begin{tabular}{ccc}
\hline Ion & $m / z$ & $I, \%$ \\
\hline$\left[\mathbf{2} \mathbf{b} @ \mathbf{6} \cdot \mathrm{PF}_{6}\right]^{+}$ & 955 & - \\
{$\left[\mathbf{2} \mathbf{c} @ \mathbf{6} \cdot \mathrm{PF}_{6}\right]^{+}$} & 1043 & - \\
{$\left[\mathbf{2} \mathbf{d} @ \mathbf{6} \cdot \mathrm{PF}_{6}\right]^{+}$} & 1131 & - \\
{$\left[\mathbf{2} \mathbf{e} @ \mathbf{6} \cdot \mathrm{PF}_{6}\right]^{+}$} & 917 & 38 \\
{$\left[\mathbf{2} \mathbf{6} @ \mathbf{6} \cdot \mathrm{PF}_{6}\right]^{+}$} & 1005 & 100 \\
{$\left[\mathbf{2} \mathbf{g} @ \mathbf{6} \cdot \mathrm{PF}_{6}\right]^{+}$} & 1093 & 50 \\
\hline
\end{tabular}

Such a spectral pattern is typical for most of rotaxanes and pseudorotaxanes ${ }^{[28-31]}$ and indicates the formation of pretty stable complexes of fluorenocrownophanes $\mathbf{2 b}$-g with paraquat $6 \cdot 2 \mathrm{PF}_{6}$, which supposedly possess a pseudorotaxane-like structure. Among the fluorenocrownophanes 2e-g with naphthalene fragments the most intensive molecular peak of a complex ion observed for the crownophane $\mathbf{2 f}$ where the aromatic fragments are linked by tetraethylene glycol residues, while less intensive peaks are observed for crownophanes $\mathbf{2 g}$ and $\mathbf{2 e}$. As the intensity ratio for the peaks of complex ions of structurally similar ligands correlates to the stability of the complexes in the first approximation, it can be suggested that under the mass spectral experiment conditions the most stable complex is formed in the case of crownophane $\mathbf{2 f}$. In the case of bis(fluoreno)crownophanes $\mathbf{2} \mathbf{b}$-d the intensity of peaks of the corresponding complex ions was very low, which proves only the fact of formation of these complexes without the possibility to make any conclusions about their stability. The peaks of the ions corresponding to $\left[\mathbf{2 a} @ \mathbf{6} \cdot \mathrm{PF}_{6}\right]^{+}$ complex particles were not detected under any experimental conditions. This allows to conclude $\mathbf{2 a}$ does not form a complex with paraquat $6 \cdot 2 \mathrm{PF}_{6}$ under the conditions of a mass spectral experiment.

During the addition of paraquat $6 \cdot 2 \mathrm{PF}_{6}$ to acetonitrile solutions of fluorenocrownophanes $\mathbf{2 b}$-g an intense pink or crimson-red color appears. A broad band appears in the visible region of the UV-Vis spectra $(496-530 \mathrm{~nm})$. The appearance of this band is due to the formation of a charge transfer complex (CTC) between the $\pi$-donor aromatic cyclophane fragments and the $\pi$-acceptor dipyridylic frame of paraquatdication $6^{2+}$ (Figure 4 ) in the cavity of the macrocycle. ${ }^{[33-35]}$ It indicates the formation of relatively stable host-guest complexes, similarly to those observed previously. ${ }^{[15]}$

The most intensive CTC bands are observed for crownophanes $\mathbf{2 c}$ and $\mathbf{2 f}$ with tetraethylene glycol, which is due to the greater stability of the corresponding complexes. Crownophane 2a was not studied by this method because of its insufficient solubility. However, even when such solvents as $\mathrm{CH}_{3} \mathrm{NO}_{2}$ and DMF were used, no visual change of color was observed, which indicates the absence of formation of the corresponding complex particles.

At a qualitative level complex formation can also be studied by ${ }^{1} \mathrm{H}$ NMR. ${ }^{[17-19,21-24]}$

The measurements were made for fixed concentrations of components in a mixture of $\mathrm{CD}_{3} \mathrm{CN}-\mathrm{CDCl}_{3}$ (4:3). For comparison, spectra of paraquat and the corresponding
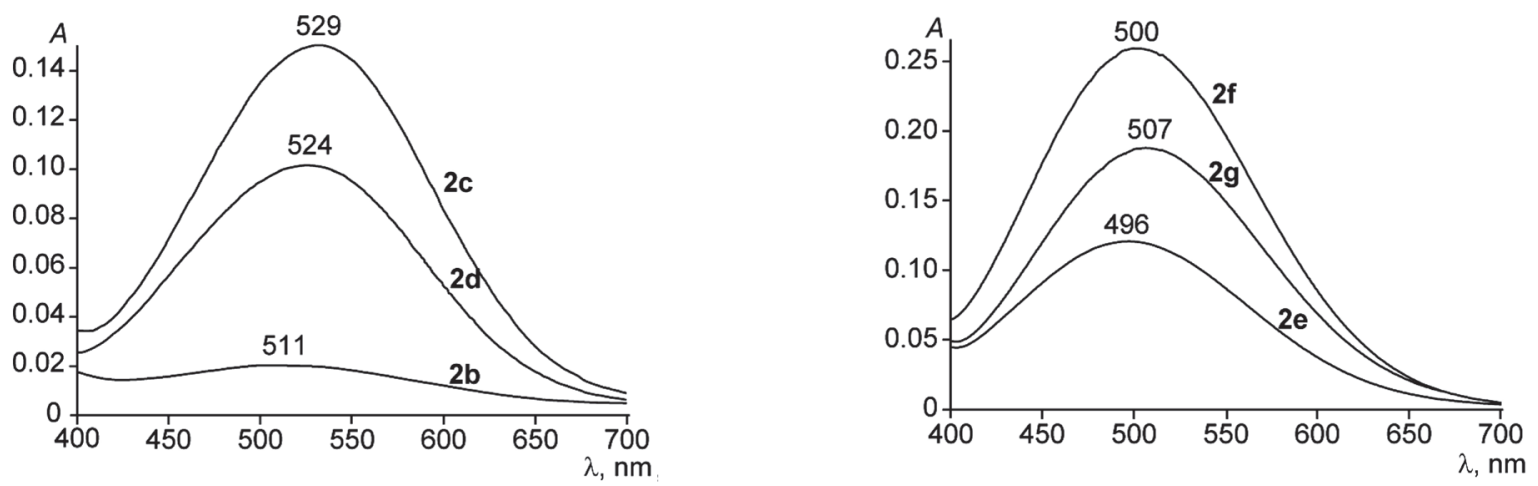

Figure 4. Normalized absorption spectra of mixtures of fluorenocrownophanes $\mathbf{2 b}-\mathbf{g}$ with paraquat $\mathbf{6} \cdot 2 \mathrm{PF}_{6}(1: 10)$ in $\mathrm{CH}_{3} \mathrm{CN}$. 
fluorenocrownophanes were recorded under the same conditions. The bis(fluoreno)crownophanes 2a-d were not studied because of their very low solubility which did not allow to reach the necessary concentration of the components.

Upfield shifts compared to the chemical shifts in spectra of individual compounds were observed for the aromatic fragments of crownophanes and paraquat, as well as for fluorene $\mathrm{H}_{9}$ protons in the ${ }^{1} \mathrm{H}$ NMR spectra of equimolar mixtures of fluorenocrownophanes $2 \mathrm{e}-\mathrm{g}$ with paraquat $6 \cdot 2 \mathrm{PF}$ (Table 3, Figure 5). It clearly indicates the formation of hostguest complexes because only in this case there can be mutual shielding of the two aromatic fragments of the crownophane and the pyridyl rings of paraquat-dication $6^{2+}$. $^{[33]}$

The largest upfield shifts of aromatic and $\mathrm{H}_{9}$ proton signals are observed for crownophane $\mathbf{2 f}$. Because the magnitude of the upfield shift reflects the degree of the overlap of the opposite aromatic fragments of crownophanes and paraquat, in the first approximation it can be considered proportional to the stability of the corresponding complexes. Hence crownophane $\mathbf{2 f}$ forms a more stable complex with paraquat than the $2 \mathrm{e}$ and $\mathbf{2 g}$. It is important to note that the magnitudes of the shifts of $\mathrm{H}_{\alpha}$ and $\mathrm{H}_{\beta}$ paraquat protons observed in case of complexes with naphthalene-containing fluorenocrownophanes $\mathbf{2 e - g}$ are the largest among all crownophanes studied by us. ${ }^{[17,19,21-24]}$ An interesting fact is that the shift of $\mathrm{H}_{9}$ protons is almost zero for $[\mathbf{2} \mathbf{e} @ \mathbf{6}]^{2+}$ complex. It can be caused by two reasons: the structure of this complex has significant differences from the complexes of larger crownophanes, or the shielding effect of paraquat-dication is comparable to one of a naphthalene fragment shielding $\mathrm{H}_{9}$ protons in a non-complexed crownophane.

\section{Conclusions}

Summing up the obtained spectral data it can be concluded that fluorenocrownophanes with tri-, tetraand pentaethylene glycols residues form relatively stable complexes with paraquat $6 \cdot 2 \mathrm{PF}_{6}$ that are stabilized by $\pi-\pi$ donor-acceptor interactions. The most stable complexes are formed by crownophanes with tetraethylene glycol linkers. The smallest crownophane with diethylene glycol residues does not form host-guest complexes under the conditions of the conducted experiments.

Further accumulation of experimental material, extension of the series of electrons-deficient guests and determination of the corresponding complex stability constants will allow to study the discovered dependencies and make more unambiguous conclusions about the structure of the formed complexes.

Table 3. Induced chemical shifts $(\Delta \delta)$ of the aromatic protons of the crownophanes $2 \mathrm{e}-\mathrm{g}$ and paraquat $6 \cdot 2 \mathrm{PF}_{6}$ in ${ }^{1} \mathrm{H}$ NMR spectra of their equimolar mixtures in $\mathrm{CD}_{3} \mathrm{CN}: \mathrm{CDCl}_{3}, 4: 3$ at $298 \mathrm{~K}$.

\begin{tabular}{|c|c|c|c|c|c|c|c|c|c|}
\hline \multirow{2}{*}{ Compound } & \multicolumn{9}{|c|}{$-\Delta \delta$} \\
\hline & $\mathrm{H}_{\mathrm{a}}$ & $\mathrm{H}_{\mathrm{b}}$ & $\mathrm{H}_{\mathrm{c}}$ & $\mathrm{H}_{9}$ & $\mathrm{H}_{2,6}$ & $\mathrm{H}_{3,7}$ & $\mathrm{H}_{4,8}$ & $\mathrm{H}_{\alpha}$ & $\mathrm{H}_{\beta}$ \\
\hline $2 \mathrm{e}$ & 0.18 & 0.13 & 0.26 & 0.02 & 0.09 & 0.01 & 0.34 & 0.27 & 0.83 \\
\hline $2 f$ & 0.22 & 0.22 & 0.36 & 0.23 & 0.01 & -0.03 & 0.30 & 0.45 & 0.89 \\
\hline $2 \mathrm{~g}$ & 0.12 & 0.11 & 0.23 & $\sim 0.16^{1}$ & 0.01 & 0.05 & 0.16 & 0.31 & 0.59 \\
\hline
\end{tabular}

${ }^{1}$ The exact determination of $\Delta \delta$ is complicated by the overlapping of the signals of $\mathrm{H}_{9}$ protons and $\mathrm{CH}_{2} \mathrm{O}$ groups.

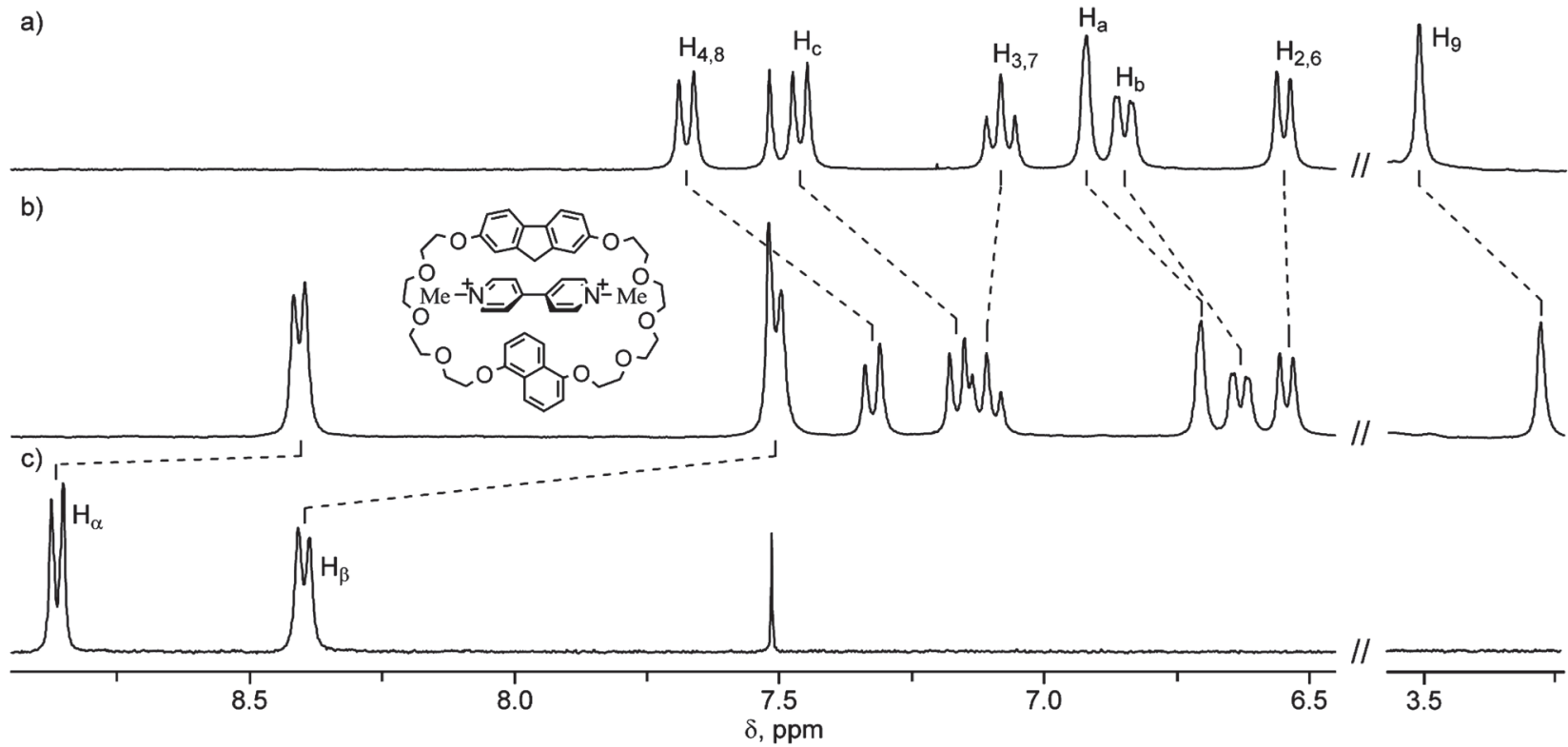

Figure 5. Parts of the ${ }^{1} \mathrm{H}$ NMR spectra of crownophanes $2 \mathbf{f}(\mathrm{a})$, paraquat $\mathbf{6} \cdot 2 \mathrm{PF}_{6}$ (c) and their equimolar mixture $(\mathrm{b})$ in $\mathrm{CD}_{3} \mathrm{CN}-\mathrm{CDCl}_{3}, 4: 3$. 


\section{References}

1. Van Dongen S.F.M., Cantekin S., Elemans J.A.A.W., Rowan A.E., Nolte R.J.M. Chem. Soc. Rev. 2014, 43, 99-122.

2. He Z., Jiang W., Schalley C.A. Chem. Soc. Rev. 2015, 44, 779789.

3. Gil-Ramirez G., Leigh D.A., Stephens A.J. Angew. Chem. Int Ed. 2015, 54, 6110-6150.

4. Langton M.J., Beer P.D. Acc. Chem. Res. 2014, 47, 1935-1949.

5. Balzani V., Venturi M., Credi A. Molecular Devices and Machines - a Journey into the Nano World. Weinheim: WileyVCH, 2003. 511 p.

6. Loeb S.J. Chem. Soc. Rev. 2007, 36, 226-235.

7. Lehr J., Beer P.D. Chem. Commun. 2014, 50, 5678-5687.

8. Belfield K.D., Bondar M.V., Morales A.R., Yavuz O., Przhonska O.V. J. Phys. Org. Chem. 2014, 16, 194-201.

9. Geng Y., Chen A.C.A., Ou J.J., Chen S.H., Klubek K., Vaeth K.M., Tang C.W. Chem. Mater. 2003, 15, 4352-4360.

10. Perepichka D.F., Bryce M.R., Perepichka I.F., Lyubchik S.B., Christensen C.A., Godbert N., Batsanov A.S., Levillain E., McInnes E.J.L., Zhao J.P. J. Am. Chem. Soc. 2002, 124, 14227-14238.

11. Domercq B., Grasso C., Maldonado J.-L., Halik M., Barlow S., Marder S.R., Kippelen B. J. Phys. Chem., B. 2004, 108, 8647-8651.

12. Bürgi L., Richards T.J., Friend R.H., Sirringhaus H. J. Appl. Phys. 2003, 94, 6129-6137.

13. Gaylord B.S., Heeger A.J., Bazan G.C. J. Am. Chem. Soc. 2003, 125, 896-900.

14. Belfield K.D., Hagan D.J., Van Stryland E.W., Schafer K.J., Negres R.A. Org. Lett. 1999, 1, 1575-1578.

15. Kirichenko T.I., Lobach A.V., Lyapunov A.Yu., Kulygina C.Yu., Yakovenko I.S., Lukyanenko N.G. Macroheterocycles 2009, 2, 290-295 (in Russ.).

16. Sheldrick G.M. Acta Crystallogr. 2008, A64, 112-122.

17. Lyapunov A.Yu., Kirichenko T.I., Kulygina E.Yu., Luk'yanenko N.G. Russ. J. Org. Chem. 2005, 41, 144-150 [Zh. Org. Khim. 2005, 41, 144-149 (in Russ.)].
18. Lukyanenko N.G., Kirichenko T.I., Lyapunov A.Yu., Mazepa A.V., Simonov Yu.A., Fonari M.S., Botoshansky M.M. Chem. Eur. J. 2005, 11, 262-270.

19. Lukyanenko N.G., Lyapunov A.Yu., Kirichenko T.I. Russ. Chem. Bull., Int. Ed. 2007, 56, 986-992 [Izv. Akad. Nauk, Ser. Khim. 2007, 56, 951-957 (in Russ.)].

20. Manjula A., Nagarajan M. Arkivoc 2001, 165-183.

21. Lukyanenko N.G., Kirichenko T.I., Lyapunov A.Yu., Kulygina E.Yu. Russ. Chem. Bull., Int. Ed. 2008, 57, 1697-1702 [Izv. Akad. Nauk, Ser. Khim. 2008, 57, 1665-1670 (in Russ.)].

22. Luk'yanenko N.G., Kirichenko T.I., Lyapunov A.Yu., Kulygina E.Yu., Mazepa A.V. Russ. J. Org. Chem. 2009, 45, 304-311 [Zh. Org. Khim. 2009, 45, 313-320 (in Russ.)].

23. Lyapunov A.Yu., Kirichenko T.I., Kulygina E.Yu., Luk'yanenko N.G. Russ. J. Org. Chem. 2012, 48, 1353-1359 [Zh. Org. Khim. 2012, 48, 1358-1364 (in Russ.)].

24. Lyapunov A., Kirichenko T., Kulygina C., Zubatyuk R., Fonari M., Kyrychenko A., Doroshenko A. J. Incl. Phenom. Macrocycl. Chem. 2015, 81, 499-508.

25. Vincenti M. J. Mass Spectrom. 1995, 30, 925-939.

26. Schalley C.A., Rivera J.M., Martín T., Santamaría J., Siuzdak G., Rebek J.Jr. Eur. J. Org. Chem. 1999, 1325-1331.

27. Schalley C.A. Int. J. Mass Spectrom. 2000, 194, 11-39.

28. Allwood B.L., Spencer N., Shahriari-Zavareh H., Stoddart J.F., Williams D.J. J. Chem. Soc., Chem. Commun. 1987, 1061-1064.

29. Bryant W.S., Jones J.W., Mason P.E., Guzei I., Rheingold A.L., Fronczek F.R., Nagvekar D.S., Gibson H.W. Org. Lett. 1999, 1, 1001-1004.

30. Mahan E.J., Dennis J.A. Org. Lett. 2006, 8, 5085-5088.

31. Zhang M., Zhu K., Huang F. Chem. Commun. 2010, 46, 81318141

32. Schalley C.A. Int. J. Mass Spectrom. 2010, 194, 11-39.

33. Amabilino D.B., Stoddart J.F. Chem. Rev. 1995, 95, 2725-2828.

34. Asakawa M., Ashton P.R., Dehaen W., L'abbé G., Menzer S., Nouwen J., Raymo F.M., Stoddart J.F., Tolley M.S., Toppet S., White A.J.P., Williams D.J. Chem. Eur. J. 1997, 3, 772-787.

35. Ballardini R., Balzani V., Di Fabio A., Gandolfi M.T., Becher J., Lau J., Nielsen M.B., Stoddart J.F. New J. Chem. 2001, 25, 293-298.

Received 22.07.2015 Accepted 28.12.2015 